\title{
MEMBANGUN PERSAUDARAAN LINTAS IMAN DENGAN BERBASIS PADA KEBUDAYAAN MASYARAKAT ADAT KEI
}

\section{Yosep Harbelubun}

\begin{abstract}
Building interfaith relationship is a relevant topic for people who live in the plurality of religions and beliefs. All religions are called to maintain diversity by building interfaith relationship. A true brotherhood is the objective of building interfaith relationship. There are various ways which could be taken by religions in building interfaith relationship. Those ways could be found in all spheres of human life. One way which could be required by religions in building interfaith relationship is to go through the wisdom of local communities. This way can lead the religions to be present relevantly and contextually in society. According to the author, the local wisdom of Keiese (Kei) community has a relevance to the efforts of building interfaith relationship. The values of Keiese (Kei) local wisdom are in accordance with the universal values on religions, which could be used as a powerful way in building interfaith relationship up.
\end{abstract}

Keywords: plurality, interfaith relationship, local wisdom, familial kinship, true brotherhood, family of God.

\footnotetext{
Abstrak

Tema tentang membangun relasi lintas iman merupakan topik yang sangat relevan bagi masyarakat yang hidup dalam kemajemukan agama dan keyakinan. Agama-agama terpanggil untuk memelihara keberagaman itu dengan membangun relasi lintas iman.

* Mahasiswa Pascasarjana Program Studi MAPT angkatan 2015, Universitas Kristen Duta Wacana. Email: harbelubunyosep@yahoo.co.id

C YOSEP HARBELUBUN | DOI: 10.21460/gema.2017.21.279

This work is licenced under a Creative Commons Attribution-NonCommercial 4.0 International Licence.
} 
Sasarannya ialah terciptanya persaudaraan sejati. Ada berbagai cara yang dapat ditempuh oleh agama-agama dalam membangun relasi lintas iman. Cara-cara itu tersedia seluas bidang-bidang kehidupan manusia. Salah satu cara yang dapat ditempuh agama-agama dalam membangun relasi lintas iman adalah melalui kearifan lokal masyarakat setempat. Dengan cara itu, agama-agama dapat hadir secara relevan dan kontekstual di tengah masyarakat. Penulis melihat bahwa kearifan lokal masyarakat Kei memiliki relevansi dengan upaya untuk membangun relasi lintas iman. Nilai-nilai kearifan lokal masyarakat Kei memiliki kesesuaian dengan nilai-nilai universal pada agama-agama, sehingga dapat dipakai sebagai salah satu cara yang ampuh dalam membangun relasi lintas iman.

Kata-kata kunci: pluralitas, relasi lintas iman, kearifan lokal, kekerabatan familial, persaudaraan sejati, keluarga Allah.

\section{PENDAHULUAN}

Di Indonesia, pluralitas adalah sebuah keniscayaan, sebab di bumi Nusantara ini hidup bersama dan berdampingan orang-orang dari berbagai latar belakang suku, bahasa, ras, agama, dan golongan yang berbeda-beda. Sebagai bagian dari Indonesia, masyarakat Kei juga hidup dalam keragaman. Kei tidak hanya menjadi tempat huni orang-orang Kei, tetapi juga menjadi "rumah bersama" bagi orang-orang dari berbagai suku bangsa. ${ }^{1}$

Sejarah pembentukan masyarakat Kei sendiri sesungguhnya telah menunjukkan wajah plural. Penduduk Kei merupakan kumpulan berbagai kelompok orang yang secara bergelombang datang dan kemudian menempati tanah Kei. Karena itu penduduk Kei saat ini sesungguhnya adalah hasil migrasi berbagai kelompok orang yang datang dari berbagai tempat di Nusantara ini dan membentuk sebuah masyarakat. Jika mengacu pada hikayat atau tradisi setempat, orang Kei meyakini bahwa leluhur mereka berasal dari Bal (Bali). Selain Bali, orang Kei juga meyakini negeri asal leluhur mereka berasal dari Dalo Ternat (Jailolo dan Ternate), Seran Ngoran (Pulau Seram dan juga wilayah Gorom di Maluku Tengah), Sumbau (Pulau Sumbawa), dan juga dari Vutun (Buton).

Selain keragaman asal-usul itu, orang Kei juga menganut agama yang berbeda-beda. Pada mulanya, sebelum masuknya pengaruh luar dengan agama-agama yang dibawa, masyarakat Kei menganut sistem kepercayaan primitif. Masyarakat Kei pada saat itu meyakini adanya pengaruh 
yang masih sangat kuat dari roh atau kuasa lain di luar kekuatan manusia bagi hidup manusia. Demikian halnya dengan kepercayaan akan pengaruh yang kuat dari roh-roh orang yang telah meninggal terhadap kehidupan sehari-hari. Praktik-praktik animisme dan dinamisme berjalan hingga masuknya agama-agama samawi.

Islam merupakan agama yang pertama masuk ke Kepulauan Kei, dibawa oleh para pedagang dan para mubalig yang datang untuk berdagang serta menyebarkan ajaran agama Islam. Menyusul agama Katolik yang masuk ke Kepulauan Kei pada tahun 1889, ditandai dengan dilaksanakannya permandian terhadap salah satu putri dari Langgur yang bernama Maria Sakbau oleh Pastor Johanes Kusters, SJ. Misi Gereja Katolik di Kepulauan Kei sebenarnya datang dari inisiatif seorang pengusaha berkebangsaan Jerman Adolf Langen, seorang yang beragama Protestan. Melihat kehidupan orang Kei saat itu yang masih tertinggal dengan praktik-praktik yang masih sangat kuat menyatu dengan alam, ia meminta kepada Vikaris Apostolik Batavia untuk mengirim para misionaris ke Kei. Jauh sebelum itu, sesungguhnya Gereja Katolik telah lebih dulu masuk ke Maluku melalui misi St. Fransiscus Xaverius yang bertolak dari Malaka pada tanggal 1 Januari 1546 dan berlabuh di Selat Amboina, kemudian tinggal di pulau itu hingga pertengahan bulan Juni. Setelah itu ia mengunjungi pulau-pulau lainnya di Maluku, termasuk Ternate dan Moro. Segera setelah hari raya Paskah tahun 1546, ia kembali ke Pulau Ambon, dan kemudian menuju Malaka. Fransiscus Xaverius bekerja di Maluku antara tahun 1546-1547 dan membaptis beberapa ribu penduduk setempat (http://nusal-chatarina.blogspot.co.id/2013/03/ masuknya-agama-katolik-di-indonesia.html). Misi di Ambon menjadi salah satu awal sejarah Gereja Katolik di Indonesia. Agama Kristen Protestan yang dibawa oleh bangsa Belanda kemudian disebarkan oleh para misionaris dan guru-guru jemaat yang direkrut dari masyarakat pribumi. Gereja Kristen Protestan sendiri sampai ke Maluku pada saat Verenigde Oost-Indische Compagnie (VOC) berkuasa pada abad ke-17 dan 18. Kehadiran para pendeta dan ziekentrooster (perawat orang sakit) bukan saja dimanfaatkan oleh gereja untuk melayani pegawai VOC, tetapi juga untuk memelihara orang-orang Kristen Ambon yang sebelumnya menganut agama Katolik Roma (hasil dari misi St. Fransiscus Xaverius). Mereka dijadikan penganut Protestan ketika penguasa VOC mengambil alih kekuasaan di Ambon dari tangan Portugis pada tahun 1605 (Müller-Krüger, 1959: 29-31). Dan, sejak tahun 1635 diadakan pekabaran Injil ke Pulau Kei, kemudian Aru, Tanimbar, dan pulau-pulau Selatan Daya (Babar, Wetar, Leti, dan sebagainya) dengan memakai tenaga guru. Sampai dengan abad ke-18 kekristenan telah diterima oleh orangorang Maluku yang terhimpun dalam jemaat-jemaat dan tersebar di hampir seluruh daerah Kepulauan Maluku (Müller-Krüger, 1959: 41). 
Latar belakang hidup masyarakat Kei yang beragam agama ini membuat topik "Membangun Relasi Lintas Iman dengan Berbasis pada Kebudayaan Masyarakat Adat Kei” menjadi sangat penting. Topik ini sesungguhnya mengungkapkan keyakinan bahwa nilai-nilai kebudayaan atau kearifan lokal masyarakat Kei memiliki relevansi dengan nilai-nilai universal pada agama-agama, sehingga dapat dipakai sebagai salah satu cara yang ampuh dalam membangun relasi lintas iman. Keyakinan ini berangkat dari fakta bahwa konflik yang terjadi di Ambon dan berimbas ke daerahdaerah lain di Maluku, termasuk di Kei, akhirnya dapat diselesaikan dengan begitu cepat (di Kei) berkat nilai-nilai kearifan lokal masyarakat adat Kei.

Demikian, tulisan ini akan dibagi dalam tiga bagian besar: 1) diangkat beberapa bentuk kearifan lokal masyarakat Kei sebagai dasar perekat relasi lintas iman, sekaligus menarik relevansinya dalam membangun relasi lintas iman; 2) berdasarkan nilai-nilai perekat relasi lintas iman dalam kearifan lokal masyarakat Kei itu, hendak ditunjuk pijakan-pijakan teologis yang memiliki kesesuaian dengan nilai-nilai kearifan lokal masyarakat Kei dalam membangun relasi lintas iman; 3) diberikan beberapa rekomendasi berangkat dari kearifan lokal masyarakat Kei dan pijakan-pijakan teologis dalam membangun relasi lintas iman yang berbasis pada kebudayaan masyarakat adat Kei.

\section{KEARIFAN LOKAL MASYARAKAT KEI SEBAGAI DASAR DAN PEREKAT RELASI LINTAS IMAN}

\section{Berapa Bentuk Kearifan Lokal Mayarakat Kei}

\section{a. Hukum Adat Larvul Ngabal}

Orang Kei memiliki sebuah hukum adat yang berisi seperangkat pedoman arah dan norma perilaku untuk melindungi dan melestarikan nilai-nilai hakiki jati diri orang Kei, yakni Hukum Adat Larvul Ngabal. Nama Larvul Ngabal menunjuk pada meterai yang menandakan pemakluman dan penerimaan hukum tersebut oleh dua kelompok masyarakat Kei zaman dulu. Larvul berarti "darah merah" merupakan meterai penerimaan hukum oleh kelompok Ursiuw (Kelompok Sembilan), sedangkan Ngabal berarti “tombak dari Bali” menjadi meterai pemakluman hukum bagi kelompok Lorlim (Kelompok Lima) (Ohoitimur, 2011: 13).

Hukum adat Larvul Ngabal dikenal sebagai warisan kultural Kei yang mengekspresikan nilai-nilai hakiki dan berfungsi untuk menjamin harmoni sosial serta kesejahteraan hidup bersama. 
Karena itu, hukum adat Larvul Ngabal dilihat sebagai sistem peraturan-peraturan yang secara tradisional dianut sebagai norma-norma yang mengatur kehidupan bersama sesuai nilai-nilai dasar yang diyakini (Ohoitimur, 2011: 2). Hukum adat Larvul Ngabal dari dulu hingga kini menjadi patokan hidup serta bertindak masyarakat Kei, tidak hanya sebatas wilayah adat tetapi melingkupi semua bidang kehidupan. Cakupan hukum adat tersebut tampak pada pasal-pasalnya yang berisi nilai-nilai hidup universal. Hukum adat Larvul Ngabal memiliki tujuh pasal sebagai berikut.

1) Uud entauk atvunad = 'kepala kita bertumpuh pada tengkuk'; maknanya, orang tua, orang yang punya kedudukan di atas secara hierarkis, pemimpin, atasan, haruslah dihormati. Pasal ini mewajibkan hormat dan patuh kepada orang tua, orang yang dituakan, atasan, dan Tuhan.

2. Lelad ain fo mahiling = 'leher kita harus dihormati atau diluhurkan'; maknanya, hidup bersifat luhur, karena itu harus dihormati, tidak boleh dilecehkan. Inilah pasal yang secara eksplisit mewajibkan penghargaan terhadap hidup dan kehidupan. Manusia bermartabat luhur.

3. Ulnit envil atumud = 'kulit membungkus tubuh kita'; maknanya, jangan memfitnah, nama baik harus dipulihkan. Pasal ini menghendaki relasi sosial yang harmonis, saling menghargai dan melindungi.

4. Lar nakmod ivud = 'darah tinggal tenang dalam perut kita'; maknanya, jangan membunuh, jangan melakukan tindakan kekerasan terhadap tubuh. Pasal ini menolak segala bentuk kekerasan dan tindakan yang melukai serta merusak tubuh.

5. Rek fo kelmutun $=$ 'perbatasan (ambang abu) harus dihormati'; maknanya, perempuan bermartabat luhur, dan itu terekspresi dalam sikap hormat laki-laki terhadap perempuan. Pasal ini mengatur batas-batas moral pergaulan antara lelaki dan perempuan.

6. Moryain fo mahiling = 'kemurnian perkawinan harus dihormati'; maknanya, perkawinan itu bermartabat mulia; hak-hak orang yang telah menikah harus dihormati. Pasal ini menjadi sumber moral perkawinan orang Kei. Segala kerumitan adat perkawinan orang Kei merupakan penjabaran pasal ini dan pasal 5 di atas.

7. Hira ni ntub fo $i$ ni, it did ntub fo it did = 'milik orang lain tetap sebagai miliknya dan milik kita tetap sebagai milik kita'; maknanya, hak orang lain harus dihormati, jangan mencuri. Inilah pasal yang secara khusus mengedepankan prinsip keadilan dalam kehidupan sosial (Ohoitimur, 2011: 15). 
Pasal-pasal hukum adat Larvul Ngabal ini dengan tegas menggarisbawahi "rasa hormat" yang harus tetap dijaga dalam hidup bersama: hormat terhadap pimpinan/orang tua (pasal 1); hormat terhadap kehidupan, hidup sendiri, dan orang lain (pasal 2, 3, 4); hormat terhadap perempuan dan rumah tangga orang; menjaga sopan santun dalam pergaulan (pasal 5 dan 6); dan hormat terhadap hak milik orang lain (pasal 7). Menurut temanya, pasal-pasal hukum Larvul Ngabal dibagi dalam tiga bagian sesuai dengan fungsinya, yakni: hukum Navnev tentang "kehidupan manusia" (pasal 1, 2, 3, dan 4), hukum Hanilit tentang "kesusilaan/moral" (pasal 5 dan 6), dan hukum Hawear Balwirin tentang "keadilan sosial" (pasal 7).

Umumnya, pasal-pasal hukum adat Larvul Ngabal berfungsi untuk menjamin harmoni sosial serta kesejahteraan hidup bersama. Dalam hubungan dengan relasi lintas iman, pasal 2, 3, dan 4 dapat menjadi dasar bertindak bagi orang Kei. Sejatinya, pasal-pasal ini menekankan penghargaan terhadap martabat luhur manusia. Tiga pasal melarang segala praktik yang sifatnya merusak kehidupan manusiawi, seperti: penganiayaan, pembunuhan, dan berbagai tindak kriminal lain. Dalam konteks relasi lintas iman, tiga pasal ini mengingatkan orang Kei untuk menghargai keragaman yang ada dengan tidak menganiaya, membunuh, dan melakukan tindak kriminal lain terhadap hidup orang lain yang berbeda latar belakang agama. Dari uraian di atas, jelaslah bahwa hukum adat orang Kei menempatkan penghargaan terhadap kemanusiaan dan moralitas sebagai dasar menghormati keragaman. Jadi human dignity mendahului keragaman dalam bentuk apa pun.

\section{b. Prinsip Hidup Ain Ni Ain ${ }^{2}$}

Prinsip hidup ain ni ain sesungguhnya menegaskan kesadaran masyarakat Kei yang melihat dirinya sebagai "satu keluarga" di mana anggota-anggotanya "saling memiliki" (ain ni ain), dalam arti bertalian dalam kekeluargaan. Ohoitimur menjelaskan ikatan kekerabatan familial itu sebagai berikut:

Dalam kenyataannya orang Kei mengerti "keluarga" tidak sebatas "keluarga batih" (ayah-ibu-anak), melainkan selalu "keluarga luas" (extended family) yang mencakup baik keluarga dari marga ibu maupun dari marga ayah. Perjumpaan antara orang-orang Kei, baik di Pulau Kei maupun di negeri rantau pun, umumnya mengalami transformasi menjadi pertemuan antara anggota keluarga. Walaupun de facto individu-individu yang berjumpa itu belum tentu atau sama sekali tidak memiliki pertalian sedarah. Orang Kei memiliki kencenderungan untuk dengan segera melacak asal-usul familial. Meski tidak ada hubungan darah secara langsung, tetapi lacakan ala Kei tersebut akan berakhir dengan spontanitas untuk saling menyapa sebagai "bapa”, “mama”, “paman”, “tante”, “kemenakan”, “kakak”, “adik”, “anak”, "cucu", dan seterusnya. Sapaan-sapaan itu secara langsung mendudukkan seseorang dalam struktur hierarkis familial di mana si A dan B menerima satu sama lain dan saling mengakui sebagai anggota satu keluarga dalam arti sebenar-benarnya (Ohoitimur, 2015: 261-262). 
Cara orang Kei menempatkan sesama dalam jalinan kekeluargaan ini sesungguhnya mengacu pada falsafah hidup fuut ain mehe ngifun ('kantong telur seekor ikan yang sama'), manut ain mehe tilur ('butir-butir telur seekor ayam yang sama'). Menurut Ohoitimur, falsafah ini mengandung pengertian sebagai berikut:

Persatuan atau kekerabatan diumpamakan dengan satu kantong telur yang mengandung banyak butirbutir bakal telur. Persatuan itu utuh dan melindungi semua yang di dalamnya. Tidak satu pun bakal telur terletak di luar kantong telur. Kehidupan yang sejati hanya mungkin dalam persatuan. Berikutnya, kantong telur (ngifun) itu milik satu ekor ikan (fuut ain mehe). Di sini hendak ditekankan alasan persatuan, yaitu asal-usul yang sama, dari satu induk.

Telur-telur menunjuk pada individu atau orang per orang yang berasal dari satu ayam atau induk yang sama. Ayam di sini melambangkan seorang ibu, yang tidak saja melahirkan anak-anak, melainkan terutama menjadi alasan persatuan anak-anaknya. Simbolisme ini sekaligus mengekspresikan paham kearifan lokal orang Kei yang memandang perempuan atau ibu sebagai pemersatu atau perekat persatuan (Ohoitimur, 2015: 262).

Prinsip hidup ain ni ain sesungguhnya mencerminkan cara orang Kei memaknai keragaman dalam satu persekutuan, yakni persekutuan kekeluargaan. Keragaman tetap diterima sebagai sebuah keniscayaan melalui penerimaan dan pengakuan terhadap yang lain sebagai keluarga. Inilah ciri kehidupan sosial kebudayaan Kei. Dengan ciri ini, orang Kei dapat dengan mudah membangun persaudaraan lintas iman.

\section{c. Perempuan Kei sebagai "Pemersatu"}

Salah satu kearifan lokal yang patut diangkat berkaitan dengan relasi lintas iman adalah sistem perkawinan yang menempatkan perempuan sebagai pusat pemersatu antara dua keluarga besar. Kedudukan dan peran perempuan itu diungkapkan lewat sebutan bagi kedua keluarga besar yang bertemu dalam peristiwa perkawinan itu dengan "pihak pemberi perempuan" (mangohoi) dan "pihak penerima perempuan" (yanur). ${ }^{3}$

Perkawinan di Kei selalu melibatkan dua belah pihak, yakni marga pemberi perempuan dan marga penerima perempuan, dan tidak semata-mata menjadi urusan seorang laki-laki dan seorang perempuan beserta keluarga batihnya. Melalui perkawinan ini, secara definitif kedua pihak membentuk satu keluarga besar yang disebut kekerabatan yanur-mangohoi. Disebut "definitif" karena ikatan kekerabatan itu dapat dijejaki sejauh-jauhnya ke belakang sampai mencapai generasi kesembilan (Ohoitimur, 2015: 263). ${ }^{4}$ Relasi kekeluargaan yanur-mangohoi ini tetap lestari bahkan sampai melewati kematian.

Relasi kekeluargaan ini sesungguhnya sudah dimulai sejak pertunangan, yakni melalui sebuah ritual perkawinan adat di mana pihak yanur menyerahkan harta kawin (vat vilin) kepada 
pihak mangohoi. Harta kawin ini lebih bernilai simbolik, yaitu sebagai tanda transformasi relasi yang menempatkan rahanyam (marga) yang anak-anaknya kawin itu dalam satu jalinan kekeluargaan. Relasi kekeluargaan yang menempatkan perempuan sebagai pemersatu ini juga tampak dalam peristiwa kematian untuk menjelaskan bahwa relasi itu bersifat definitif. Dalam praktik yang masih berlaku sampai sekarang, pihak mangohoi maduan (keluarga dari ibu si mati) memberikan bakvil baklof matmatan (pakaian untuk dikenakan si mati) dan pihak mangohoi utin (keluarga nenek si mati menurut garis ibu) memberikan buut barit (perlengkapan dan pembungkus peti jenazah si mati). Praktik ini bertujuan untuk merawat relasi kekeluargaan yang didasarkan pada kedudukan ibu. Dalam relasi kekeluargaan itu ibu atau garis perempuan memainkan peranan kunci sebagai pemersatu (Ohoitimur, 2015: 265). Salah satu contoh konkrit bagaimana orang Kei menempatkan perempuan sebagai faktor perekat persatuan atau persaudaraan, yakni dalam hal penyelesaian masalah. Dalam praktik sehari-hari, perempuan atau ibu memegang peranan yang sangat penting untuk merekatkan kembali relasi kekeluargaan yang terputus karena masalah tertentu. Masalah dengan mudah diselesaikan jika ibu atau saudari perempuan dilibatkan dalam proses penyelesaiannya. Alasannya adalah karena orang Kei menghormati perempuan atau ibu, baik menurut garis keturunan maupun secara moral. ${ }^{5}$ Jadi, kiranya jelas bahwa dalam masyarakat Kei posisi perempuan menentukan stabilitas kekerabatan secara sosial.

Tema tentang membangun persaudaraan lintas iman sesungguhnya mengungkapkan kesadaran agama-agama dalam mengupayakan kehidupan yang rukun dan harmonis. Upaya itu harus melibatkan partisipasi aktif semua orang dan berbagai elemen. Sayangnya, sering kali masyarakat (dan agama-agama) kurang memberi kesempatan kepada perempuan untuk ikut serta secara formal dalam gerakan membangun persaudaraan lintas iman. Kiranya, posisi perempuan sebagai stabilisator kekerabatan sosial di Kei, dapat menjadi inspirasi bagi agama-agama dalam upaya membangun persaudaraan lintas iman.

\section{d. Pendatang dalam Perspektif Orang Kei}

Salah satu kearifan lokal lain yang memungkinkan relasi lintas iman dapat dibangun dengan mudah di Kei adalah cara orang Kei memperlakukan orang pendatang (= mav, bisa dimengerti dalam arti "negeri asing atau tanah yang jauh", dan "bayangan atau sombar"). Orang Kei menyatakan sikapnya terhadap orang pendatang (orang bukan Kei) dengan mengangkat (mengadopsi) mereka menjadi melmel marvutun (sebutan kepada golongan pendatang yang diberi kedudukan tinggi). Orang Kei melihat orang yang datang dari mav (negeri yang hanya dapat dilihat secara samarsamar; itulah dunia kayangan, tempat tinggal para dewa) sebagai utusan dewa, lebih pandai dan 
bijaksana. Paham ini menyebabkan orang Kei sangat menghormati pendatang dan membuka pintu keluarganya kepada orang-orang asing (Ohoitimur, 2015: 267).

Bentuk penghormatan orang Kei terhadap pendatang itu dapat dijejaki hingga awal mula sejarah kepemimpinan di Kei. Karisma yang dimiliki oleh para pendatang dengan membawa berbagai peralatan yang dianggap sakral serta keahlian, kepiawaian, kepandaian, dan kelicikan mereka menimbulkan rasa hormat dan kepatuhan yang sangat besar sehingga kepada mereka diserahi jabatan kepemimpinan.

\section{Relevansinya dalam Membangun Relasi Lintas Iman}

Apa yang dapat dikatakan tentang kearifan lokal masyarakat Kei dalam perspektif relasi lintas iman? Ada beberapa butir yang dapat ditarik dari kearifan lokal masyarakat Kei dalam membangun relasi lintas iman.

1. Nilai-nilai yang terkandung dalam hukum adat orang Kei bersifat universal dalam arti merupakan nilai-nilai kemanusiaan. Nilai-nilai tersebut melampaui batas-batas suku, ras, agama, dan golongan, serta dapat diterima oleh siapa pun. Dalam arti itu, nilai-nilai hukum Larvul Ngabal ini dapat dijadikan pijakan dalam membangun relasi lintas iman.

2. Prinsip hidup ainni ain yang menegaskan persatuan dalam kepelbagaian hidup orang Kei, dengan berdasar pada falsafah fuut ain mehe ngifun, manut ain mehe tilur yang mengungkapkan bagaimana orang Kei melihat dirinya sebagai satu anggota keluarga dapat menjadi dasar dan sarana dalam membangun relasi lintas iman di Kei. Bagi orang Kei, agama-agama samawi baru datang kemudian. Hal yang lebih dulu ada, yaitu rasa kekeluargaan dalam satu kesatuan hidup. Oleh karena itu, sesungguhnya tidaklah sulit bagi orang Kei untuk membangun relasi lintas iman atas dasar rasa kekeluargaan yang merupakan inti jati diri kultural orang Kei. Relasi lintas iman dengan mudah dapat dibangun ketika orang menyadari bahwa sesungguhnya mereka adalah satu keluarga.

3. Relasi kekeluargaan yang dibangun melalui perkawinan dengan perempuan sebagai perekat pemersatu dalam tradisi etnis orang Kei dapat menjadi dasar bagi orang Kei dalam menjaga persekutuan hidup. Perempuan menjadi pilar persatuan dan perawat relasi lintas iman. Di sini mencuat inspirasi tentang peranan perempuan dalam gerakan pengembangan persaudaraan lintas iman.

4. Sikap orang Kei terhadap pendatang, orang asing, dan tamu memperlihatkan bagaimana orang Kei tidak hanya memahami keluarga sebatas pertalian darah atau yang sesuku, tetapi 
juga menjangkau semua orang dari berbagai macam latar belakang. Sikap dan praktik seperti ini mempermudah relasi lintas iman bukan hanya dengan orang-orang sedarah atau sesuku tetapi juga dengan mereka yang datang dari luar.

5. Masih bisa ditambahkan di sini beberapa bentuk kearifan lokal masyarakat Kei lain yang memiliki relevansi dengan upaya membangun persaudaraan lintas iman. Misalnya, teabel $^{6}$ sebagai sebuah bentuk perjanjian adat (antara dua kampung atau dua persekutuan adat yang terdiri dari beberapa kampung) untuk saling membantu dan terlibat dalam kehidupan sebagai saudara. Perjanjian adat itu menempatkan kedua belah pihak dalam posisi yang sederajad, yakni sebagai saudara yang harus dihargai, dilayani, dan diperhatikan. Dan, koi maduan $^{7}$ yang sejatinya menggambarkan cara orang Kei menempatkan dua belah pihak (antar dua keluarga dalam sebuah perkawinan dan antar dua kampung) dalam relasi saling membantu sebagai satu keluarga.

\section{LANDASAN TEOLOGIS BAGI PEMAKNAAN KEMAJEMUKAN}

Ada dua teks atau ayat Kitab Suci yang dapat dijadikan pijakan teologis dalam membangun relasi lintas iman di tengah kehidupan masyarakat Kei yang beragam agama, yakni: Kejadian 9:16 dan Roma 2:1-16. Uraian atas kedua teks tersebut adalah sebagai berikut.

\section{Semua Manusia Membentuk Satu Keluarga Allah}

Kitab Kejadian 9:16, "Jikabusurituada diawan, makaAku akan melihatnya, sehinggaAkumengingat perjanjian-Ku yang kekal antara Allah dan segala makhluk yang hidup, segala makhluk yang ada di bumi." Ayat ini menyatakan bahwa Allah membarui perjanjian-Nya, perjanjian keselamatan dengan seluruh ciptaan-Nya. Pelangi di awan menjadi lambang pengharapan (lihat Pesan Natal bersama 2015 PGI dan KWI). Dalam bukunya Dari Eden ke Babel, Singgih menempatkan Kejadian 9:16 dalam konteks "Kiprah Manusia Pasca-Air Bah” (Kej. 9:1-29) (Singgih, 2011: 232). Apa yang terjadi dengan manusia sesudah peristiwa Air Bah? Sesudah peristiwa Air Bah, Tuhan mengadakan perjanjian dengan manusia (Nuh dan anak-anaknya) dan seluruh makhluk hidup ciptaan-Nya (Kej. 9:8-17). Marsunu dalam bukunya Dari Penciptaan sampai Babel menempatkan Kejadian 9:16 ini dalam konteks "Perjanjian Allah dengan Nuh". Menurut Marsunu, berbeda dengan perjanjian Allah dengan Abraham yang hanya mengikat Abraham dan keturunannya (Kej. 17), demikian 
halnya perjanjian Allah dengan Musa yang hanya mengikat bangsa Israel (Kel. 19), perjanjian Allah dengan Nuh ini melibatkan Nuh, keturunannya, dan seluruh makhluk hidup (Marsunu, 2008: 107-108). Isi perjanjian itu adalah Tuhan berjanji untuk tidak lagi menghancurkan bumi dengan air bah atau semacamnya. Allah mengadakan perjanjian ini dengan penuh kesungguhan. Kesungguhan Allah ini diwujudkan dengan tanda perjanjian. Menurut Singgih, ayat 16 merupakan bagian dari tanda perjanjian yang diberikan Tuhan, yang disebut-Nya sebagai "perjanjian kekal” (Singgih, 2011: 246). Tanda perjanjian berupa "busur" ini yang lazimnya ditafsirkan sebagai pelangi. Tanda perjanjian itu ditaruh di awan sehingga setiap orang dapat melihatnya dan meyakini bahwa Allah setia berpegang pada janji-Nya untuk tidak lagi menghukum manusia. Busur (= pelangi) menjadi tanda jaminan kedamaian oleh Allah.

Manakah kaitan dari Kejadian 9:16 ini dengan topik relasi lintas iman?

1. Perjanjian yang diadakan Allah dengan melibatkan Nuh, keturunannya, dan seluruh makhluk hidup mengandung makna universalitas (Martasudjita, 1999: 70). Itu artinya, Allah-lah yang menciptakan semua makhluk, dan karenanya menjadi Allah semua makhluk. Dalam konteks pluralitas, DIA adalah Allah semua orang. Allah adalah Bapa semua orang. Ia "menerbitkan matahari bagi orang yang jahat dan orang yang baik dan menurunkan hujan bagi orang benar dan orang tidak benar" (Mat. 5:45). Dalam konteks membangun relasi lintas iman, keyakinan akan Allah sebagai Bapa semua orang ini mengundang kita untuk semakin rela dan suka berdialog dengan umat dari agama-agama lain. Dalam semangat dan suasana dialog inilah suatu persaudaraan sejati dapat dibina (Martasudjita, 1999: 72). Allah menjadi perekat pemersatu semua umat manusia.

2. Dalam kaitan dengan "Allah adalah Bapa semua orang" ini, kita dapat menerima konsep "semua orang membentuk satu keluarga Allah". Tanda perjanjian berupa pelangi dapat bermakna "kepelbagaian dalam satu ikatan" (Bhineka Tunggal Ika). Kepelbagaian itu terberi, sudah ada sejak awal penciptaan, berasal dari Allah dan karena itu indah pada dirinya (seperti pelangi). Singgih memberi contoh lagu anak-anak yang biasanya dinyanyikan bagi seorang anak menjelang ditidurkan untuk menggambarkan keindahan dalam kepelbagaian itu sebagai berikut, "Pelangi, pelangi, alangkah indahmu... pelukismu agung, siapa gerangan... pelangi, pelangi, ciptaan Tuhan" (Singgih, 2011: 232). Jika dikaitkan dengan topik relasi lintas iman, maka makna Kejadian 9:16 sebagai berikut: ayat ini mengingatkan kita bahwa semua orang itu sesungguhnya adalah "keluarga Allah", yang dituntun oleh pelangi kasih-Nya yang meneguhkan iman dan menguatkan harapan. Sebagai satu anggota 
keluarga, kita masing-masing mempunyai tanggung jawab untuk menjadikan hidup bersama di bumi ini semakin baik; bukan hanya tanggung jawab untuk keselamatan manusia, tetapi juga untuk keutuhan seluruh ciptaan. Demikian pula, kita diingatkan bahwa umat Kristiani tidak hidup sendiri sebagai komunitas tertutup di dunia ini. Gereja hidup berdampingan dengan komunitas-komunitas lain (lihat Pesan Natal bersama 2015 PGI dan KWI).

Konsep "keluargaAllah" ini sejalan dengan konsep "kekerabatan familial” dalam masyarakat Kei. Baik konsep "keluarga Allah" maupun konsep "kekerabatan familial” ala Kei, kedua-duanya bercorak universal dan inklusif. Unsur pengikat atau perekat dalam "keluarga Allah" adalah Allah sendiri dan dalam "kekerabatan familial” ala Kei adalah perempuan. Baik Allah maupun perempuan (makhluk ciptaan-Nya), kedua-duanya adalah asal kehidupan. Kendati berbeda tingkatannya, dan bahwa perempuan itu diciptakan oleh Allah, sama seperti Allah, perempuan pun "menciptakan" kehidupan. Dari keduanya jalinan kehidupan itu menjalar dan berkembang. Sama seperti Allah diagungkan dan dimuliakan oleh umat beriman karena DIA-lah asal mula kehidupan (causa prima $=$ penyebab pertama), demikian halnya perempuan dalam masyarakat Kei dihormati dan dijunjung karena dialah "asal kehidupan" dan simbol pemersatu orang Kei. Dalam bingkai pemahaman seperti ini, sesungguhnya tidaklah sulit bagi orang Kei untuk membangun relasi lintas iman.

\section{Umat Beragama Lain Di Mata Orang Kristiani}

Perikop Roma 2:1-16 menjadi titik pijak untuk menjelaskan bagaimana orang Kristiani menempatkan diri terhadap umat beragama lain. Perikop ini dibagi dalam dua bagian: Roma 2:1-11 yang berbicara tentang "alternatif religius dalam kehidupan"; dan, Roma 2:12-16 yang berbicara tentang "Taurat bukanlah suatu keistimewaan" (Bergant, 2002: 253). Pada perikop Roma 2:1-16, kita dapat melihat bagaimana Rasul Paulus memposisikan orang Kristiani terhadap orang beragama lain. Prinsip dasariah yang membimbing cara berpikir Paulus di sini diungkapkan dalam ayat 11, "sebab Allah tidak memandang bulu" (mengingat diskusi dalam Gal. 2:1-10). Hendaknya jangan seorang pun merasa diistimewakan atau dikecualikan dari penghakiman Allah (Bergant, 2002: 253). Secara implisit uraian Paulus dalam perikop Roma 2:1-11 ini mendudukkan orang Kristiani dengan umat beragama lain setara di hadapan Allah. Setiap orang, siapa pun dia (tidak peduli apakah itu orang Yahudi atau Yunani) akan mendapat ganjaran setimpal dengan perbuatannya (baik atau buruk). Terkait dengan ganjaran Allah atas perbuatan manusia ini, Paulus menguraikannya dengan lebih rinci dalam Roma 2:12-13. Ia berbicara tentang orang-orang Yahudi dan orang kafir di hadapan Allah. Bagi orang Yahudi maupun orang kafir, sama-sama diganjari 
Tuhan berdasarkan perbuatan mereka. Bukan hukum atau aturan (Taurat) yang menjadi ukuran ganjaran Allah tetapi perbuatan seseorang. Bergant menjelaskan sebagai berikut.

Meskipun orang-orang kafir tidak memiliki Taurat (Taurat bukanlah suatu keistimewaan), namun mereka dibimbing oleh pengalaman tuntutan transendensi kehendak Allah. Refleksi batin mereka akan mempersoalkan baik dan buruknya tindakan mereka. Jika mereka melakukan kebaikan, maka itu akan menguntungkan mereka. Bila tidak, hal itu akan merupakan penghakiman bagi mereka. Begitu juga dengan cara pandang orang Yahudi. Yang penting dan menyelamatkan bagi mereka bukannya masalah memiliki Taurat atau tidak. Yang diperhitungkan adalah bagaimana menaati atau melanggar Taurat (Bergant, 2002: 253).

Hal yang menarik di sini, menurut Bergant, Paulus menempatkan posisi Yesus sebagai hakim pada pengadilan terakhir baik bagi orang Yahudi maupun orang kafir masing-masing sesuai dengan perbuatan mereka. ${ }^{8}$ Dari perikop Roma 2:12-13, kita bisa melihat bagaimana seharusnya orang Kristiani menempatkan diri terhadap orang-orang yang tidak beragama (kafir). Ukuran yang dipakai untuk menilai keselamatan orang-orang kafir adalah pada perbuatan mereka. Dokumen Konsili Vatikan II, ${ }^{9}$ Konstitusi Dogmatis tentang Gereja (Lumen Gentium, 16) memberi pendasaran penting tentang bagaimana seharusnya sikap orang Kristiani terhadap orang beragama lain dan orang yang tidak beragama.

Sebab mereka yang tanpa bersalah tidak mengenal Injil Kristus serta Gereja-Nya, tetapi dengan tulus hati mencari Allah, dan berkat pengaruh rahmat berusaha melaksanakan kehendak-Nya yang mereka kenal melalui suara hati dengan perbuatan nyata, dapat memperoleh keselamatan kekal. Penyelenggaraan ilahi juga tidak menolak memberi bantuan yang diperlukan untuk keselamatan kepada mereka, yang tanpa bersalah belum sampai kepada pengetahuan yang jelas tentang Allah, namun berkat rahmat ilahi berusaha menempuh hidup yang benar. Sebab apa pun yang baik dan benar, yang terdapat pada mereka, oleh Gereja dipandang sebagai persiapan Injil, dan sebagai kurnia Dia, yang menerangi setiap orang, supaya akhirnya memperoleh kehidupan (Hardawiryana,1993: 87-88. Lihat juga Go dan Suharto, 1990: 27).

Tentang posisi kristianitas di hadapan agama-agama non-Kristen ini, Karl Rahner menyampaikan sebuah teori yang dikenal dengan teori Kristen anonim (anonymous Christian). Teori ini didasarkan atas refleksinya tentang rahmat yang menjangkau semua ciptaan sejak dunia dijadikan. Rahner mengatakan: "Manusia secara individual—karena bukan kesalahannya sendiri tidak mengenal kristianitas - tetap punya kesempatan untuk diselamatkan. Dia disebut Kristen anonim atau beriman Kristiani secara implisit, sejauh dia mendengarkan suara hati, mempraktikkan iman, harapan, dan kasih" (Samosir, 2010: 90-91).

Bagi Rahner, penganut agama lain mungkin menemukan karunia Yesus melalui agama mereka sendiri tanpa harus masuk menjadi penganut Kristen. Oleh karenanya orang tidak harus secara eksplisit masuk menjadi penganut agama Kristen agar mendapatkan kebenaran dan 
memperoleh keselamatan itu. Bertitik tolak dari pemahaman di atas, Rahner lalu mengatakan bahwa "agama lain adalah sebenarnya bentuk implisit dari agama yang kita anut" (Suratno, 2008: 2). ${ }^{10}$ Dari sini menjadi jelas bahwa Rahner mempercayai kebenaran dan keselamatan dimungkinkan ada pada agama lain, namun agama yang dipeluknya tetap dipercaya memiliki kebenaran yang "lebih".

Teori Rahner ini memperlihatkan sebuah paham inklusivisme yang bertentangan dengan eksklusivisme. Lama sekali gereja berpegang pada semboyan extra ecclesiam nulla salus (di luar gereja tidak ada keselamatan). Semboyan ini mengungkapkan, bahwa keselamatan itu hanya bisa dicapai, kalau orang menjadi anggota gereja (dan dengan demikian mengakui Yesus Kristus sebagai penyelamat). Bertentangan dengan paham ekslusivisme ini para teolog inklusivisme menghasilkan teori pemenuhan, manusia itu haus akan Yang Ilahi. Oleh karena itu, kristianitas merupakan titik puncak, sedangkan agama-agama lain merupakan preparasi menuju wahyu Allah dalam Yesus Kristus ini (Samosir, 2010: 89).

Melanjutkan refleksi teologis atas posisi orang Kristiani terhadap agama-agama lain, muncul pula para teolog pluralisme. Para teolog pluralisme menolak eksklusivisme karena eksklusivisme mengandaikan kebenaran utuh yang dipegang oleh gereja. Demikian halnya dengan inklusivisme yang menghapus fungsi agama non-Kristiani dalam keselamatan. Mereka beranggapan bahwa inklusivisme masih tidak tulus.

Para teolog pluralisme ini bukan hanya mempertanyakan, apakah yang bukan Kristen bisa selamat, tetapi di mana posisi agama lain dalam tatanan keselamatan. Mereka berangkat dari pandangan "Allah" sebagai misteri yang tak tertangkap. Agama-agama itu berusaha menangkap "Yang Ilahi" ini dalam kerangka masing-masing dan mengekspresikannya dengan "bahasa" masing-masing. Para teolog pluralisme agama mengakui realitas plural ini bukan hanya sebagai de facto, tetapi de iure (Samosir, 2010: 89-90).

Salah satu teolog pluralisme yang terkenal adalah Raimundo Panikkar. Sebagaimana para teolog pluralisme agama yang lain, Panikkar tidak puas dengan sikap inklusivis (yang tetap melihat Yesus dan kristianitas sebagai norma untuk menilai orang-orang beragama lain). Dia juga bersama para teolog pluralis lain mencari posisi agama-agama lain di dalam tatanan keselamatan. Pertanyaannya bukan lagi: apakah orang yang beragama lain akan selamat, tetapi: apakah agama lain menjadi jalan keselamatan bagi para penganutnya (Samosir, 2010: 91-92). Menurut Panikkar, setiap orang sungguh-sungguh mencari Tuhan. Mencari Tuhan itu adalah pengalaman asli setiap orang. Panikkar menyebut pengalaman asli itu sebagai iman yang dibedakannya dengan kepercayaan. Iman adalah hubungan dengan yang transenden (Sudiarja, 1994: 56). Pengalaman 
asli ini membuat gambaran Allah menjadi plural, terlebih ketika iman diwujudkan dalam ideide dan rumusan-rumusan (itulah kepercayaan) (Sudiarja, 1994: 56-57). Tentang hal ini, Panikkar menegaskan:

"Bagaimapun juga pengalaman iman adalah pengalaman manusia yang tidak akan termuat dalam sesuatu rumusan, tetapi dalam kenyataan tersurat dalam apa yang sudah saya sebut sebagai rumusanrumusan kepercayaan. Manusia terpaksa mengutarakan kesan-kesannya yang paling dalam, tetapi untuk itu dia harus menggunakan bahasa yang menjalin ungkapan itu dengan tradisi manusia yang ada, dia mempertahankan gambaran-gambaran dan simbol-simbol yang menjadi bagian dari kelompok budayanya. Dia akan membuat imannya dikenal dalam serangkaian kepercayaan yang mungkin akan dia sebut dogma-dogma, yang mengungkapkan apa yang dia maksudkan dalam istilah-istilah intelektual. Jelas bahwa istilah-istilah itu mungkin beraneka ragam; kenyataannya memang harus pluralistik" (Sudiarja, 1994: 61).

Itulah sebabnya, bagi Panikkar, jika ingin berbicara tentang Allah atau agama, Allah atau Yang Ilahi itu sendiri, beragam bukan hanya satu seperti halnya agama-agama. Dengan demikian, Panikkar menolak semua definisi pluralisme agama yang menyimpulkan bahwa agama-agama men-share common essence (hal-hal esensial yang sama) dan menyatakan bahwa masing-masing agama mengekspresikan sebuah bagian penting dari kebenaran (Tanoto, 2009). Justru dalam keberagaman itulah dialog lintas iman dimungkinkan terjadi. Karena itu dalam upaya membangun dialog lintas iman, Panikkar menggarisbawahi hal penting ini, "Kita harus bekerja keras untuk memahami masing-masing agama dalam bahasanya sendiri-sendiri yang konsepnya berbedabeda" (Tanoto, 2009).

Uraian di atas memperlihatkan sebuah perkembangan maju dalam teologi Kristen. Berangkat dari posisi Yesus dalam tatanan keselamatan seperti disampaikan Alkitab (dalam konteks tulisan ini, Rasul Paulus), teologi Kristen akhirnya sampai pada penegasan yang sangat mengagumkan berkaitan dengan bagaimana orang Kristiani seharusnya menempatkan diri terhadap umat beragama lain seperti disampaikan oleh para teolog pluralisme agama.

Singkatnya, dalam konteks relasi lintas iman, perikop Roma 2:1-16 memberi dua pendasaran penting bagi orang Kristiani dalam menempatkan diri terhadap umat beragama lain, yakni:

\section{Dasar Pertama}

a. Bahwa hanya Allah sumber cinta kasih dalam kehidupan. Karena itu, Santo Paulus menegaskan bahwa di hadapan Allah semua manusia itu beroleh cinta kasih Allah yang tulus. Cinta kasih Allah bukanlah monopoli sekelompok orang. Cinta kasih Allah diberikan pada setiap orang sehingga mereka pun akhirnya menuju kepada Allah. 
b. Cinta kasih Allah tidak terbatas, Allah sangat kaya, maka dengan keberagaman keyakinan manusia dipanggil untuk mengungkapkan cinta kasih Allah yang tak terbatas.

c. Setiap orang dipanggil untuk menjadi saudara bagi sesamanya sehingga mereka dapat berjalan bersama menuju Allah.

2. Dasar Kedua

a. Kristus mengutus gereja untuk hidup di dunia. Sejak Konsili Vatikan II, gereja menempatkan diri terhadap umat beragama lain sebagai teman seperjalanan menuju kepada Allah, Sang Sumber Kehidupan.

b. Dalam kebersamaan sebagai rekan seperjalanan, gereja diutus oleh Kristus untuk memperlihatkan dan menyalurkan cinta kasih Allah kepada semua orang dan segala bangsa (Ad Gentes 10) (Hardawiryana,1993: 414).

c. Perutusan itu hanya dapat dilaksanakan gereja dengan tetap berada dan menjadi bagian dalam kehidupan masyarakat. Masyarakat merupakan media kesaksian yang mana gereja dapat menghadirkan cinta kasih Allah kepada manusia.

d. Kesaksian yang diwartakan gereja harus bersifat kontekstual, artinya dalammelaksanakan perutusan itu gereja hendaknya dengan sungguh-sungguh memperhatikan konteks kehidupan sosial, budaya, dan tradisi kebangsaan dan keagamaan, serta keprihatinan/ masalah yang ada dan dihadapi masyarakat di mana gereja berada.

Pokok tentang bagaimana orang kristiani menempatkan diri terhadap umat beragama lain seperti sudah diuraikan di atas memiliki kesejajaran dengan ciri kekerabatan familial orang Kei, terkhusus cara orang Kei memperlakukan pendatang, orang asing, dan tamu. Orang Kei sangat menghormati pendatang dan membuka pintu keluarganya kepada orang-orang asing. Dasar dari sikap hormat ini adalah pengakuan akan adanya kebaikan pada diri yang lain sebagaimana orang Kei melihat pendatang sebagai orang-orang yang memiliki kepandaian dan kebijaksanaan tertentu.

Pijakan-pijakan teologis di atas mencuatkan sejumlah pertanyaan, apa peran dan kontribusi agama dalam membangun persaudaraan lintas iman di Kei? Pada tatanan manakah agama-agama telah membangun persaudaraan lintas iman tersebut? Bagaimana agama-agama meyakinkan para pemeluknya bahwa sejatinya semua orang beragama itu adalah satu keluarga Allah? Konflik bernuansa agama di Kei dalam tahun 1999-2000 menyatakan bahwa ternyata agama dapat diperalat oleh dan untuk kepentingan tertentu yang mengakibatkan kehidupan masyarakat terpecah-belah. Agama-agama yang sejatinya adalah "kedamaian", oleh dan untuk kepentingan tertentu, dapat 
berubah menjadi agama yang berwajah "kekerasan". Sementara di lain pihak, nampaknya agamaagama sulit menemukan solusi yang tepat dalam penyelesaian konflik. Sebaliknya, dengan nilai-nilai dan adat istiadat yang terpusat pada kekeluargaaan atau kekerabatan, orang Kei dapat menyelesaikan konflik dengan baik.

Keadaan ini semestinya mendorong agama-agama untuk berefleksi dan merumuskan kembali kehadirannya secara baru dalam konteks masyarakat Kei yang bersaudara. Apa yang harus dibuat oleh agama-agama?

1. Konsep yang ditawarkan oleh para teolog pluralisme agama semestinya menjadi acuan bagi agama-agama untuk merumuskan kehadirannya secara kontekstual. Keragaman adalah konteks hidup masyarakat Kei. Namun, keragaman itu diikat oleh rasa kekeluargaan sebagai ciri sosial kebudayaan Kei. Para teolog pluralis menekankan pentingnya "menghargai perbedaan/keragaman", sementara kebudayaan Kei menempatkan "keragaman dalam bingkai kekeluargaan”. Bertitik tolak dari pandangan para teolog pluralis dan kearifan lokal Kei, maka agama-agama harus tampil sebagai lembaga yang memberi penghargaan tinggi pada keragaman dan menempatkan keragaman itu dalam satu ikatan kekeluargaan. Dengan jalan ini, agama-agama dapat memberi kontribusi bagi terbentuknya sebuah persekutuan hidup yang universal, yakni sebagai keluarga Allah.

2. Setiap agama lahir dari tradisi yang berbeda-beda dan dipengaruhi oleh tradisi-tradisi itu. Meskipun berbeda-beda, tradisi agama-agama dapat diterima oleh kebudayaankebudayaan masyarakat lokal. Ketika berbicara tentang identitas kulturalnya, orang Kei selalu melihat agama sebagai sesuatu yang memisahkan, namun sejatinya mereka adalah satu keluarga. Dalam konteks seperti ini, agama-agama tertantang untuk merumuskan kembali kehadirannya sebagai instansi yang "bukan memisahkan" tetapi "mempersatukan". Bagaimana agama-agama menyakinkan masyarakat etnis bahwa agama itu tidak memisahkan, tidak mengotak-ngotakkan atau bahkan cenderung memecah-belah? Sekali lagi, sumbangan para teolog pluralis semestinya menjadi acuan bagi agama-agama untuk berbicara tentang hal ini. Para teolog pluralis tidak hanya menekankan keragaman sebagai sebuah kenyataan yang harus dihargai, tetapi pula menempatkan keragaman itu dalam satu posisi yang sejajar. Bertitik tolak dari pandangan para teolog pluralis, maka agamaagama harus merevisi cara-cara pengajaran atau pendalaman iman yang mengarah pada sentimen-sentimen negatif dan yang kelak membentuk sikap fanatisme sempit atau bahkan radikalisme. Dengan cara ini, agama-agama dapat menghadirkan wajah yang lebih familiar 
(akrab) bagi masyarakat setempat. Hal ini penting, karena relasi lintas iman harus dimulai dari keyakinan bahwa semua orang sederajat dan dimungkinkan terjadi jika tidak ada satu agama pun yang mengklaim diri lebih superior dari yang lain serta menjadi norma final dari norma-norma yang lain.

\section{REKOMENDASI BAGI UPAYA MEMBANGUN PERSAUDARAAN LINTAS IMAN}

Uraian tentang kearifan lokal masyarakat Kei dan pijakan-pijakan teologis di atas memperlihatkan simpul-simpul pada titik-titik tertentu antara keduanya dalam membangun relasi lintas iman. Oleh karena itu, berikut ini kami akan memberikan beberapa rekomendasi yang kiranya penting diperhatikan dalam membangun relasi lintas iman dengan berbasis pada budaya tradisional masyarakat adat Kei.

1. Relasi lintas iman harus dibangun dengan sebuah kesadaran bahwa gereja dibentuk di dalam partikularitas dan kelokalan. Gereja tidak pernah lepas dari lingkungan di mana dia hidup. Gereja adalah bagian dari masyarakat di mana gereja berada. Karena itu, masyarakat adalah "milik" gereja; sebaliknya, gereja adalah "milik" masyarakat. Segala keprihatinan masyarakat adalah juga keprihatinan gereja. Singkatnya, gereja bukan sebuah instansi abstrak-universal yang tidak tersentuh oleh pertanyaan dan jawaban lokal (lihat uraian lengkap dalam Samosir, 2010: 82-84). Partikularitas dan kelokalan gereja dalam konteks tulisan ini adalah masyarakat Kei yang plural. Di tengah masyarakat Kei yang jamak ini, gereja harus hadir membawa ciri dan semangat "semua orang adalah keluarga Allah".

2. Berkaitan dengan partikularitas dan kelokalan ini, kontekstualisasi atau inkulturasi menjadi salah satu cara gereja bisa hadir di tengah masyarakat secara efektif dan efisien. Menurut Singgih, "Secara sederhana kontekstualisasi berarti usaha menemukan harga diri sendiri sebagai orang Kristen di dalam konteks kita berada. Konteks kita adalah kebudayaan setempat" (Singgih, 2000: 24). Kontekstualisasi atau inkulturasi juga dapat dimengerti sebagai cara gereja menyesuaikan diri dengan kebudayaan lokal (de Jong dan Tridarmanto, 2015: 27). Dalam konteks keberagaman agama, kontekstualisasi mendorong gereja untuk menggunakan "satu bahasa", yakni bahasa budaya setempat. Menurut hemat kami, bahasa budaya dapat menjadi jembatan yang menghubungkan para pemeluk agama yang berbeda dan memungkinkan adanya relasi lintas iman dalam keberagaman itu. Di sini, yang dimaksud 
dengan bahasa budaya setempat adalah nilai-nilai kearifan lokal. Jauh sebelum agamaagama masuk ke Kei, orang Kei telah menghidupi nilai-nilai kearifan lokal yang sejalan dengan nilai-nilai Injili. Nilai-nilai itu terkandung dalam: Hukum Adat Larvul Ngabal dengan pasal-pasalnya yang berfungsi untuk menjamin harmoni sosial serta kesejahteraan hidup bersama, prinsip hidup ain ni ain sebagai jiwa persekutuan hidup orang Kei, posisi perempuan sebagai pemersatu hidup orang Kei, dan cara orang Kei memperlakukan pendatang sebagai bagian dari keluarga. Nilai-nilai kearifan lokal ini hendaknya menjadi pijakan bagi gereja untuk hadir secara kontekstual di tengah masyarakat Kei yang beragam agama. Dengan kearifan lokal yang ada gereja bersama-sama dengan agama-agama dapat membangun relasi lintas iman.

3. Dalam upaya membangun persaudaraan lintas iman dengan berbasis pada kebudayaan masyarakat Kei, gereja harus menyadari pentingnya membangun komunikasi dan kerja sama dengan berbagai elemen masyarakat. Komunikasi dan kerja sama ini penting karena gereja menyadari diri sebagai bagian kecil saja dari masyarakat dan tidak akan bisa banyak berbicara tanpa hal itu. Komunikasi dan kerja sama itu dapat ditempuh melalui dua cara, yakni:

a. Dengan Pemerintahan Adat. Komunikasi dan kerja sama dengan pemerintahan adat berangkat dari adanya fakta bahwa sekarang ini nilai kekeluargaan sebagai jati diri masyarakat Kei sedang menghadapi ancaman. Masyarakat Kei sekarang ini hidup di tengah transisi arus modernisasi dan budaya tradisional yang menghadirkan banyak perubahan dalam kehidupan orang Kei. Salah satu perubahan yang mendasar di Kei saat ini terkait erat dengan cara orang Kei memandang dan bersikap terhadap sesama dalam kekerabatan familial. Orang Kei saat ini tidak mudah lagi merasa ain ni ain (perasaan saling memiliki) terhadap sesama kecuali dengan kepentingan tertentu. Perubahan itu berdampak pada adanya konflik yang marak terjadi akhir-akhir ini (batas tanah/petuanan dan kepemimpinan/kepala kampung) sebagai jiwa interaksi sosial. Dalam situasi seperti ini, gereja perlu membangun kerja sama yang sinergis dengan (pemerintahan) adat dalam upaya memberi penyadaran tentang pentingnya persatuan dan membina masyarakat melalui kegiatan-kegiatan yang bermanfaat untuk merekatkan mereka satu dengan yang lain.

b. Dengan Agama-Agama. Gereja harus menjadi komunitas yang terbuka dalam mempromosikan semangat kekeluargaan ini. Karena itu komunikasi dan kerja sama 
dengan agama-agama lain adalah modal selanjutnya untuk bisa berbicara tentang persekutuan keluarga Allah. Untuk maksud itu,gereja perlu menjadi yang terdepan dalam membangkitkan kesadaran masyarakat tentang pentingnya menjaga dan memelihara persatuan dan kesatuan, dengan cara tampil sebagai instansi pemersatu sesuai dengan keyakinan bahwa semua orang adalah keluarga Allah. Hal itu mungkin terjadi, jika secara internal gereja menjadikan persatuan itu dasar dari perjalanannya dan dengan itu dapat menjadi inspirasi bagi upaya membangun persaudaraan lintas iman.

4. Butir pertama sampai ketiga di atas memberi tekanan pada kekerabatan familial sebagai jati diri kultural orang Kei dalam upaya membangun persaudaraan lintas iman. Tekanan itu tidak menutup kemungkinan bagi nilai-nilai kearifan lokal lain yang sesungguhnya dapat dijadikan rekomendasi bagi lembaga agama dan adat dalam upaya membangun persaudaraan lintas iman. Pada konteks ini, kita berbicara tentang nilai-nilai universal yang mengikat semua orang dari beragam latar belakang yang berbeda dalam satu jalinan relasi lintas iman. Adat dan agama memiliki hukum dan aturan yang berisi nilai-nilai universal, yakni nilai-nilai kemanusiaan. Nilai-nilai itu menjadi identitas dari tiap-tiap masyarakat adat dan agama. Dalam konteks masyarakat adat Kei, nilai-nilai universal seperti hormat pada manusia yang bermartabat luhur, persaudaraan dan persatuan, kesetiaan perkawinan dan kerukunan keluarga, dan hormat pada hak milik orang lain terkristalisasi dalam hukum adat Larvul Ngabal dan beberapa bentuk kearifan lokal. Nilai-nilai seperti itu juga ditemukan dalam agama-agama. Itulah sebabnya, adat dan agama harus secara konsisten membina masyarakat (umat) untuk mengenal, mendalami, menghayati, dan menghidupi nilai-nilai kemanusiaan itu. Dengan nilai-nilai kemanusiaan yang sifatnya universal ini, berbagai elemen masyarakat dapat bertemu dalam satu jalinan kerja sama untuk membentuk sebuah persaudaraan universal.

\section{PENUTUP}

Keberagaman agama harus diterima dalam sebuah masyarakat yang terbuka dan dirayakan sebagai sebuah kekayaan. Hal yang patut diperhatikan adalah bagaimana mengelola keberagaman agama itu menjadi sebuah berkat bagi kehidupan masyarakat. Di tengah keberagaman agama itu, kemendesakan untuk membagun relasi lintas iman/agama menjadi urgent. 
Ada berbagai macam cara yang dapat ditempuh untuk mempertemukan agama-agama yang berbeda dan mengikat mereka dalam satu-kesatuan hidup. Salah satunya adalah melalui kearifan lokal masyarakat. Setiap masyarakat etnis memiliki nilai-nilai budaya yang dapat menjadi perekat pemersatu kehidupan masyarakatnya, seperti juga pada masyarakat Kei. Ketika persoalan terjadi pada wilayah agama, kearifan lokal dapat dipakai untuk menyelesaikan persoalan antar agama dan menjadi jembatan untuk mempertemukan para pemeluk agama yang berbeda-beda itu.

\section{Catatan}

${ }^{1}$ Kepulauan Kai (atau Kei) di Indonesia berada di bagian tenggara Kepulauan Maluku, termasuk dalam Provinsi Maluku. Penduduk setempat menyebut kepulauan ini Nuhu Evav ('Kepulauan Evav') atau Tanat Evav ('Negeri Evav'), tetapi dikenal dengan nama Kei atau Kai oleh penduduk dari pulau-pulau tetangga. Istilah Kei muncul dalam komunikasi antara bangsa Eropa dengan penduduk asli ketika mereka tiba di kepulauan ini. Dalam interaksi tersebut orang Eropa bertanya tentang apa nama pulau tersebut, namun karena tidak paham dengan bahasa yang digunakan oleh orang-orang asing itu maka masyarakat setempat menjawab dengan menggunakan dialeg setempat "kai waaid” yang artinya tidak tahu, sehingga dipahami oleh orang-orang asing tersebut bahwa sesungguhnya pulau itu bernama "Kai", yang kemudian dipakai untuk menamai gugusan kepulauan itu dengan sebutan "Kai”, yang lambat laun mengalami perubahan dialektika menjadi Pulau Kei.

2 Ain ni ain secara harafiah berarti "satu punya satu", maksudnya masyarakat merupakan satu keluarga besar di mana setiap orang bertalian secara familial dengan orang lain (membentuk satu keluarga, bersaudara) (Ohoitimur, 2015: 262).

3 Bukan "pihak laki-laki" dan "pihak perempuan".

4 Kosakata bahasa Indonesia mengenal silsilah hanya sampai turunan ke-5, yaitu: anak, ayah, kakek, buyut, dan moyang. Sedangkan bahasa Kei memiliki istilah khusus sampai lapisan turunan ke-9, yaitu: yanan (anak), yaman (ayah) atau renan (ibu), buntaran (kakek) atau bunte (nenek), nisin (buyut), kikan (moyang), hareen, teon, baan (bad), lanun (Ohoitimur, 2015: 265).

5 Posisi perempuan sebagai dasar moralitas sesungguhnya ditegaskan secara eksplisit dalam pasal 5 (rek fo kelmutun) dan 6 (moryain fo mahiling) hukum Larvul Ngabal.

6 Teabel, istilah ini terdiri dari dua kata, yakni tea yang artinya 'menggores' dan bel yang berarti 'darah yang mengalir'. Jadi teabel adalah bentuk kekerabatan atau perjanjian yang diikat oleh "aliran darah".

7 Maduan (mang duan) berarti tuan, pemilik, yaitu pemilik orang, sedangkan koi (disebut juga mardu) bisa berarti "bawahan", dalam arti orang yang dibantu (Ohoitimur, 2015:266).

${ }^{8}$ Gagasan Paulus tentang peran Yesus sebagai hakim pada pengadilan terakhir oleh Konsili Vatikan II dijelaskan sebagai berikut: dalam Yesus Kristus Perantara, Allah menyelamatkan umat manusia, yang tidak disapa pribadi oleh amanat Injili, melalui tradisi-tradisi religius mereka sendiri beserta ajaran-ajaran dan praktik-praktik religius mereka (Hardawiryana, 2001: 87).

9 Konsili Ekumenis Vatikan Kedua atau Vatikan II (1962-1965), adalah sebuah Konsili Ekumenis ke-21 dari Gereja Katolik Roma yang dibuka oleh Paus Yohanes XXIII pada 11 Oktober 1962 dan ditutup oleh Paus Paulus VI pada 8 Desember 1965.

${ }^{10}$ Sebagai catatan, meskipun pandangan Rahner bersifat inklusif, ia masih menempatkan Yesus sebagai norma di mana kebenaran berada, dan jalan di mana keselamatan dapat diperoleh. 


\section{DAFTAR PUSTAKA}

Chatarina. 2013. "Masuknya Agama Katolik di Indonesia”, http://nusa1-chatarina.blogspot. co.id/2013/03/masuknya-agama-katolik-di-indonesia.html (diakses 05.03.2013).

De Jong, Kees dan Yusak Tridarmanto (eds.). 2015. Teologi dalam Silang Budaya, Yogyakarta: Yayasan Taman Pustaka Kristen Indonesia dan Fakultas Teologi UKDW.

Go, P., O.Carm dan Suharto. 1990. Kawin Campur Beda Agama dan Beda Gereja, Malang: Dioma. Hardawiryana, R., S.J. (terj.). 1993. Dokumen Konsili Vatikan II, Jakarta: Obor dan Dokpen KWI. Hardawiryana, Robert, S.J. 2001. Dialog Umat Kristiani dengan Umat Pluri-Agama-Kepercayaan di Nusantara, Yogyakarta: Kanisius.

Martasudjita, E. 1999. Allah Bapa Semua Orang, Yogyakarta: Kanisius.

Müller-Krüger, Th. 1959. Sedjarah Geredja di Indonesia, Jakarta: Badan Penerbit Kristen.

Ohoitimur, Johanis. 2015. "Ain Ni Ain: Paham Persatuan Orang Kei”, dalam Riyanto, Armada, dkk. (eds.), Kearifan Lokal-Pancasila: Butir-butir Filsafat Keindonesiaan, Yogyakarta: Kanisius.

Ohoitimur, Y., MSC. 2011. Jati Diri Kultural Orang Kei dan Hukum Adat Larvul Ngabal, Makalah, Pineleng.

PGI dan KWI. 2015. Pesan Natal Bersama.

Samosir, Leonardus, OSC. 2010. Agama dengan Dua Wajah: Refelksi Teologis Atas Tradisi dalam Konteks, Jakarta: Obor.

Seto, Marsunu, Y.M. 2008. Dari Penciptaan Sampai Babel (Ulasan Kejadian 1-11), Yogyakarta: Kanisius.

Singgih, Emanuel Gerrit. 2000. Berteologi dalam Konteks, Yogyakarta: Kanisius dan Jakarta: BPK Gunung Mulia. . 2011. Dari Eden ke Babel: Sebuah Tafsir Kejadian 1-11, Yogyakarta: Kanisius.

Sudiarja A (ed.). 1994. Dialog Intra Religius (Raimundo Panikkar), Yogyakarta: Kanisius.

Suratno. 2008. "Pluralitas Makna Pluralisme (Agama)", http://www.islamlib.com (diakses 24.03. 2008).

Tanoto, Wahyu. 2009. “Pandangan Para Teolog Tentang 'Pluralisme' Agama”, https://mumdiyati. wordpress.com/2009/01/19/pandangan-para-teolog-tentang-'pluralisme'-agama/ (diakses 19.01.2009). 